\title{
Taxation and Investment Decisions in Petroleum
}

\author{
Graham A. Davis* and Diderik Lund ${ }^{\dagger}$
}

August 21, 2018

\begin{abstract}
When governments apply high tax rates targeted at natural resource rent, there must be generous deductions in order to avoid investment disincentives. How generous is disputed. Based on standard finance theory and recommendations from the OECD and the IMF, the value that firms attach to future deductions depends on the risks of these, and the companies' after-tax weighted-average cost of capital cannot be applied directly. As an example, a simple model quantifies the difference between pre-tax and post-tax systematic risk when tax deductions are less risky than pre-tax cash flows. Osmundsen et al. (2015) suggest that the difference must be ignored by oil companies, since they cannot find the separate market values of tax deductions. But companies operating in different jurisdictions cannot then appreciate differences in tax systems, not even approximately, which will lead to suboptimal decisions. Tax designers may instead assume that companies have gradually adopted more sophisticated methods of investment decision making.
\end{abstract}

Keywords: Petroleum, tax, depreciation, uplift, investment, risk, evaluation

JEL Codes G31, H25, H32, L71, Q48

\footnotetext{
* Corresponding author: Payne Institute for Earth Resources and Division of Economics and Business, Colorado School of Mines, 1500 Illinois St., Golden, Colorado 80401, gdavis@mines.edu.

${ }^{+}$Department of Economics, University of Oslo, P. O. Box 1095, Blindern, NO-0317 Oslo, Norway, diderik.lund@econ.uio.no.
} 


\section{Introduction}

During the last forty years, the field of investment decisions has developed rapidly, both theoretically and practically. The adoption in industry of new tools does not happen simultaneously everywhere. The heterogeneity of practices is well documented. This is also true for the petroleum industry.

When governments want to collect parts of the resource rent through taxation, it is useful to be able to predict the investment and production responses of companies. Academic economists have developed theories of taxation of firms, and of the taxation of resource extraction in particular, to make these predictions. These theories rely on the assumption that the efficient firms either undertake complex value-maximizing calculations prior to making investment and production decisions, or behave "as if" they do. A particular topic that has been disputed is how generous deductions need to be in a rent tax system in order for the rent tax not to create investment and production distortions for these firms.

An article by Osmundsen et al. (2015) in a special issue of this journal devoted to Morris Adelman, who himself wrote often about the distortionary effects of taxation, discusses actual oil company treatment of deductions, with harsh criticism of petroleum taxation in Norway. This article presents a different view. ${ }^{1}$ The academic view is that firms correctly price the incentives to invest given to them by governments. Particular attention has been paid to depreciation allowances that represent risk-free income for the firm (Summers, 1987; Fane, 1987). Norway has gone to great lengths to reduce the risk connected to future tax deductions in the petroleum tax system, including surety of deduction carry-forwards. On this background the authorities assume that companies value tax deductions as if they are risk free. A review of the literature shows that practices in firms are more heterogeneous than suggested by Osmundsen et al. (2015), and that some firms report the valuation of low risk depreciation streams in line with academic predictions. This contributes to explaining why numerous academic

1 Many of the arguments have appeared in the Norwegian language in the journal Samfunnsфkonomen (Osmundsen and Johnsen, 2013; Lund, 2013, and references therein). 
articles, as well as reports on tax reform, give taxation policy recommendations that are at odds with those of Osmundsen et al. (2015).

Osmunden et al. (2015) seem confounded that standard academic theory can suggest that firms use different discount rates for different cash flow streams, and refer repeatedly to the idea that companies discount only net cash flows based on some overall project or firm discount rate. Standard theory suggests superposition, also known as value additivity: cash flows have the same value to the firm no matter how they are aggregated. The positive effect from a guaranteed depreciation allowance can therefore be valued by discounting it at the riskless rate and adding it to the present value of the other cash flows. Or, as Osmundsen et al. (2015) admit, firms may instead discount net after-tax cash flows at an opportunity cost of capital that "reflects the average risk of the resulting aggregate" (p.196), including the risk effects of the tax deductions. In Section 4 we present a simple model of investment decisions under uncertainty and taxation that illustrates how firms would make decisions in line with standard theory applied in this way.

The essential question is not, as suggested by Osmundsen et al. (2015), whether firms apply one discount rate to net after-tax expected aggregate cash flows or use different discount rates for different cash flow elements that differ in risk. Superposition implies that both approaches yield the same valuation and investment behavior. The question is the extent to which firms price fiscal policy risk into their investment decisions, and whether they get either approach to valuing such risk approximately correct. Osmundsen et al. (2015) assume that firms calculate a project's after-tax beta from an average of stock market returns, that beta having nothing to do with a presumption of a riskless or even slightly risky deduction scheme. Our model shows a reasonable approximation of how the firm may arrive at the appropriate endogenous after-tax cost of capital using this second approach, be the deduction scheme riskless or risky. We conclude that the appropriate concern is not, therefore, over firm practice, but over the factual evidence as to the riskiness of the deduction scheme in Norway. 
Section 2 describes the Norwegian petroleum tax system and the political risk connected to it. Section 3 reviews the literature. Section 4 presents the model. Section 5 gives our discussion and interpretation of the model. Section 6 concludes.

\section{Norwegian petroleum tax and risk}

Our main topics are which methods to use in evaluation of investment projects under taxation and risk and some results on effects of taxation. This section will nevertheless provide some details about petroleum taxes in Norway and the related political risk. This is useful since we comment on a previous article that is applied to Norwegian petroleum, but also as an example to make our points more concrete. However, the remaining sections can be read without a comprehensive understanding of the details. More background is found in Lund (2002a, 2014b, 2018).

Since 1992 the main features of the tax system have been unchanged from the viewpoint of a company which is never out of tax position. The system consists of a corporate income tax (CIT) and a special petroleum tax (SPT). There is no gross taxation, royalty, or similar. Neither of the two taxes is deductible in the other, so the total marginal rate is the sum of the two rates, constant at 78 percent since 1992 . Today the rates are 23 percent and 55 percent, while they were 28 percent and 50 percent during $1992-2012$. The CIT has a depreciation allowance, linear for six years, which is generally regarded as a bit too generous compared with true economic depreciation in the average project. ${ }^{2}$ Interest expenses are deductible. Exploration costs can be expensed, i.e., deducted when they are incurred.

The SPT has the same tax base as the CIT with two exceptions. There is an extra deduction, the "friinntekt," translated into English as an "uplift." This is like an extra depreciation allowance, currently of 21.2 percent, i.e., 5.3 percent of investment deductible for four years. The intention is that the CIT should tax the normal and supranormal return to capital, while the SPT should

\footnotetext{
2 There is also no inflation adjustment of depreciation allowances, also lacking in most other
} tax systems. 
only tax the supranormal return, the rent. The other exception is targeted at thin capitalization and was introduced in 2007. The interest deduction in the SPT is limited to interest expenses on debt equal to 50 percent of the remaining value of capital after tax depreciation, reduced linearly to zero in six years. Apart from this limitation, the features described above were unchanged from $1992-2012$. As a response to a gradual lowering of the CIT for other sectors in Norway from 28 to 23 percent during 2013 - 2018, the SPT rate was increased to keep the sum constant. The uplift was adjusted down from 30 to 22 percent in 2013, then lowered somewhat in 2016 and again in 2017.

There have been three other changes that only affect companies out of tax position. Since 2002 there has been loss carry-forward with interest accumulation, in order to preserve the present value of tax deductions for the companies. Since 2005 a company that has exploration costs and is out of tax position will get the tax value of the costs refunded, like a negative tax. Furthermore, a company which closes down its operations without being able to deduct losses carried forward will get the tax value of these losses refunded. In a world context these three provisions are quite unusual, although Alaska had a refund for eventual losses during some years (Bradner, 2016, 2017). In the jargon of tax economists, the three provisions will create perfect loss offset as long as they are not changed by the authorities. For this reason, the Ministry of Finance of Norway calculates the value of future tax deductions based on the presumption that firms value the deductions as a riskless revenue stream (Ministry of Finance, 2012; Jensen, 2017).

It may be useful to compare the system with rent tax systems that are known from the literature. The Resource Rent Tax (RRT) of Garnaut and Clunies Ross (1975) is different in that it is cash flow based, i.e., investments are expensed like operating costs. The Norwegian SPT is more like the Allowance for Corporate Capital (ACC) system (Boadway and Bruce, 1984). In addition to depreciation allowances, there is an extra deduction, the uplift, to protect the "normal" rate of return from the SPT. The uplift is proportional to investment, not only to the equity financed part, which is the case in the 
better-known Allowance for Corporate Equity (ACE) system (IFS, 1991; OECD, 2007). But the SPT uplift is a fixed, constant percentage of investment for four years. This differs from the ACC allowance, which each year typically is based on a market interest rate, which may vary over time. Moreover the ACC allowance is proportional to the remaining value of investment after tax depreciation, falling over time, and is thus theoretically just what is needed to protect the normal return from the tax. The SPT uplift is a simplified approximation to this. Since the SPT does not conform exactly to any of the systems known from theory, and since depreciation and interest deductions also differ from theoretical prescriptions, one needs to calculate the present value of deductions in order to evaluate whether the CIT-cumSPT system gives incentives or disincentives for investment (see Lund, 2018).

When the SPT uplift rate was held fixed for 20 years, its present value at a (time varying) market interest rate was not constant. This may have been one reason for the decision to decrease the uplift rate in 2013, since market rates had been decreasing. However, that problem is avoided in the rule for the rate used to accumulate interest on losses carried forward. This is tied to each year's market interest rate. The authorities claimed that the change in 2013 was necessary to avoid overinvestment. Lund (2018) finds that it gave such incentives if companies applied a nominal discount rate below 7.6 percent for the tax deductions, while after the change, this upper limit was reduced to 5.9 percent. ${ }^{3}$ Risk-free interest rates have been lower than this, so a substantial risk premium must be added in the discount rate if there should be disincentive effects of the tax system.

The stability of the system for many years has been noted by many. Osmundsen (2010) writes that the system has been "entirely stable in recent years" as a result of a policy of "absolute commitment” (2010, pp. 437, 441). The IMF (2012, p. 24) observes that the system is "noted for its stability." There may nevertheless be some political risk, and the value of future

\footnotetext{
3 The authorities' stated intention was that the tax system should give the same disincentive for a 50 percent leveraged investment as would occur under the CIT, alone, with 12 years linear depreciation. Lund (2018) finds that this would happen before 2012 for a company applying a nominal discount rate of 9.6 percent, lowered to 7.4 percent due to the lower uplift rate in 2013.
} 
deductions will depend on their expected values and their risk. This appears in our model in Section 4. An objective probability distribution does not exist. The reduction in the uplift rate in 2013 is the only major unanticipated change to the companies' disadvantage during 1992 - 2018. One must assume that this event has led Osmundsen to reevaluate the stability of the system, cf. the quote above compared with Osmundsen et al. (2015).

The political risk of further reductions in tax deductions should not be exaggerated. But as long as parliament is free to change future taxes, it cannot be avoided completely. ${ }^{4}$ The reduced uplift in 2013 was only made effective for licensees that had not yet filed a development plan for their license. In general, there has been strong political support for the stable system since 1992, in spite of changing governments. ${ }^{5}$ Recently a complaint has been launched against the refund of tax value of exploration costs for companies out of tax position, for a European surveillance authority, by an environmental group. ${ }^{6}$ This would, however, not affect deductions for companies that are in position to pay taxes, the main factual focus of Osmundsen et al. (2015). The refund at close-down has survived despite public attention to large refunds. For instance, when Talisman closed down in Norway in 2015, it received a refund of 3.4 billion NOK (approx. 400 million USD) due to large unclaimed deductions.

For the valuation model in Section 4 , it is important whether the political risk is systematic, i.e., correlated with market movements. We are not aware of any studies that give indications of this. Whether the expected future deductions are higher or lower than the current is not easy to judge, either. Since 2015 the tax value of the uplift rate has been kept constant through the rate changes (Lund, 2018). Our view is thus that relevant political

\footnotetext{
${ }^{4}$ Some countries offer fiscal stability contracts (Daniel and Sunley, 2010), but Norway does not. Whether such contracts can actually achieve their goal is not obvious.

5 The years 1992 - 2017 can be divided into six periods with governments of four or five political shades, with months of consecutive rule in parenthesis, Right or Center-Right coalition $(48+50)$, Center-Left (96), Labor (70+19), Center (29). These governments have maintained stable petroleum taxation. The support of the seven parties involved was 92.5 percent of votes in the parliamentary election in 2017.

${ }^{6}$ See http://www.eftasurv.int/da/DocumentDirectAction/outputDocument?docId=4123 downloaded March 14, 2018.
} 
risk is minor, especially for deductions as they apply to current licensees in tax position.

\section{Previous literature}

The current debate concerns the basic question of valuation of risky cash flows, a question that is not particular to this industry. As Myers (1984) notes, the opportunity cost of funds depends on the use of funds, not the source. Firms' investment opportunities compete with the securities shareholders can buy. We should therefore use an evaluation model which best explains the value and risks of these competing securities. "Any time a firm sets a hurdle rate based on capital market evidence, and uses a DCF formula, it must implicitly rely on the logic I have sketched” (Myers, 1984, p. 128). Textbooks (e.g., Ross et al., 2010) distinguish between three DCF methods, called Adjusted Present Value (APV), Flow to Equity (FTE), and Weighted Average Cost of Capital (WACC). Typically, they all rely on the Capital Asset Pricing Model (CAPM) (Sharpe, 1964; Lintner, 1965; Mossin, 1966) to determine the adjustment for risk, i.e., the relevant risk is a function of the covariance of the project's cash flow returns with the market portfolio.

The difference between FTE and WACC has to do with debt financing, which has not been a topic in the current debate. The difference between the APV method (Myers, 1974) and the WACC method is that the latter applies one discount rate to the net after-tax cash flows, while the former, relying on value additivity, splits the cash flows into different elements with different degrees of risk. While the focus originally was on the risk of debt tax shields, Lessard (1979) recommends also to separate out depreciation tax shields. The suggestion has been taken up by some oil industry consultants (e.g., de Souza, 2014). When different projects have different ratios of expected revenues to expected operating costs (known as different operating leverage), it will likewise be useful to distinguish between the risk of revenues and the risk of operating costs. This has been done for petroleum in Salahor (1998), Emhjellen and Alaouze (2002, 2003), and Emhjellen and Osmundsen (2011), among others. More generally, value 
additivity allows the pricing of each individual cash flow stream according to its specific risk, as emphasized in the real options treatment of valuation (Laughton 1998; Samis et al., 2006).

Of concern in Norway, and elsewhere, are operational methods for authorities attempting to capture natural resource rent through taxation without inducing distortion in investment or extraction decisions. As a theoretical reference point, we define a pure cash flow tax as a proportional tax on non-financial cash flows, with payout of negative taxes in years with negative cash flows (Brown, 1948). In the public economics literature this is seen as an ideal, non-distortionary tax, but impracticable. Instead, investments, or negative cash flows, can be deducted in the tax bases in future years in most tax systems. The idea that some future tax deductions can be seen as low-risk elements of after-tax net cash flows is found in Fane (1987) and Summers (1987). The first is an extension to uncertainty of the neutrality result of Boadway and Bruce (1984). The 1984 paper shows that a corporate income tax with a form of uplift in addition to depreciation deductions will, when firms make decisions in accordance with financial theory, not affect investment decisions when the present value of investment-related deductions is equal to investment. Fane (1987) shows that this theory holds under revenue uncertainty when the risk-free interest rate is applied, provided that the deductions will be earned sooner or later with full certainty as is the current system in Norway. Moreover, the tax rate must be constant with certainty. If it is not certain the stream of deductions becomes risky.

By now, there is a substantial academic literature on the ACC, the ACE and related systems (cf. Section 2) (see, e.g., Radulescu and Stimmelmayr, 2007, de Mooij and Devereux, 2011, and references therein). They have also been discussed in policy oriented reports, e.g., OECD (2007), and the ACE was recommended for Britain by the Mirrlees Review (Mirrlees et al., 2011).

Summers (1987) regards depreciation deductions in the U.S. as essentially risk free, i.e., they add a risk-free amount to after-tax cash flows. They should thus be discounted at the risk-free interest rate. However, his 
survey of 200 large firms in 1985 shows that they do not discount them separately. Thus they are unable to give a reasonable treatment of projects that differ from the average, due to, e.g., unusually high taxes with high, lowrisk deductions. Summers (1987) recommends that the tax system should give deductions earlier in order to counteract this tendency of misvaluation.

Osmundsen at al. (2015) are particularly persuaded by Summers' analysis. But company investment decision making has changed markedly over time (Ryan and Ryan, 2002), and surveys show a wide range of stated practices (Graham and Harvey, 2001; Brounen et al., 2004; Baker et al., 2011; Horn et al., 2015). In a 2006 survey of Canadian companies, 36\% have used APV (Baker et al., 2011). Of particular relevance, in a 2003 survey up to $10 \%$ of European companies state that they use a separate discount rate for depreciation allowances when evaluating a new project (Brounen at al., 2004). Graham and Harvey (2001) report similar results for US companies. Between $25 \%$ and $50 \%$ of firms in these surveys report instead always or almost always using an overall net cash flow discount rate that matches the risk of the project under consideration rather than a corporate cost of capital. It is very possible that such risk-matching includes the effect of a particular depreciation allowance rule.

Energy companies are reported in these surveys to be amongst the most sophisticated firms in these surveys, with many using APV. Certain major firms in the oil industry have taken up both the flexibility and superposition emphases of real options with enthusiasm (Bailey et al., 2003). And one must remember that firms may make decisions that go beyond the recommendations from the economic analysis that they explicitly conduct; consulting industry participants have noted that some firms in the industry "instinctively or intuitively view their investment opportunities as real options" (Leslie and Michaels, 1997), and recent empirical studies indicate that mining and oil and gas firm decision making is, de facto, more in line with real options theory, inclusive of its use of superposition, than with traditional DCF methods (Harchaoui and Lassere, 2001; Moel and Tufano, 2002; Muehlenbachs, 2015; Bonaime et al., 2018). In any event, while the 
exogenous discount rate evaluation practice that Osmundsen et al. (2015) suggest firms use is a frequently cited approach in these surveys, there are many companies in the surveys that state that they follow the approach presumed by academics and taxation authorities.

Osmundsen et al. (2015) advocate tax neutrality under the assumption of an industry-wide discount rate to be applied to all elements of cash flows. The impracticality of this proposal, reminiscent of a proposal by Garnaut and Clunies Ross (1975), has also been noted. In the literature on taxation of natural resource rent, a seminal article by Garnaut and Clunies Ross (1975) suggests the Resource Rent Tax (RRT) system. This has some of the properties of a neutral tax defined by Fane (1987). The tax is cash-flow based (i.e., allows immediate expensing). In a year with negative net cash flow, this should be carried forward with interest accumulation for deduction the next year, or possibly later years. But Garnaut and Clunies Ross (1975) do not suggest any eventual payout if a firm closes down before effectively deducting the negative balance. Thus, deductions will be risky. To compensate, they suggest the use of a carry-forward interest rate equal to the firm's cost of capital. In light of how they see firms discounting cash flows, Osmundsen et al. (2015) make the same argument for Norway. Several authors (Dowell, 1978; Mayo, 1979; Ball and Bowers, 1983; Smith, 1999) have pointed out the insufficiency of this arrangement. Neutrality would require that firms' valuation of a risky deduction equals the original outlay, in present value terms. But with imperfect loss offset, the risk will vary from project to project, and a suitable interest rate is hard to find. Summers (1987, p. 298) makes a similar point for business taxation in general, that a correct discount rate to reflect "average degree of riskiness" will vary with circumstances, and with the tax system in particular. By this same line of reasoning, if the deductions can be made riskless, the interest rate should be the riskless rate. It is exactly this realization that has motivated Norwegian authorities to go to great lengths to make deductions risk free.

Osmundsen et al. (2015) consider risk-free tax deductions as a purely theoretical concept, of no practical interest. Citing Fane (1987), they state that 
"This article concludes that, if the companies can be sure of receiving the deductions, they will be able to calculate their NPV at an interest-free rate. Taking a completely overarching approach to public sector economics, the article actually says nothing about the practical shaping of uplift" (p. 199; the "interest-free rate" is presumably a risk-free rate). Uplift must instead be based on company practice, which apparently does not and cannot undertake valuation using superposition because one cannot know the riskiness, and thus the appropriate discount rate, for the residual cash flow stream once the depreciation flows are removed and valued. Since companies effectively discount all risky cash flows at the same rate, taken from marketed assets with a level of risk reflecting the average project, and given that tax deductions, even though less risky than net cash flows, are still risky, the rate of uplift must reflect the firm's discount rate if it is not to distort investment decisions. The attempt by Norwegian authorities to make deductions risk free is then a futile attempt to operationalize a theoretical result.

But the existing literature conveys a different view. For instance, OECD (2007) writes, "Bond and Devereux (1995) have argued that the imputed return should not include a risk premium if the corporation considers the ACE to be a 'safe' cash flow such that its gain is not lost or reduced in present value terms. This requires that the government offers a full loss carryforward, which increases with the interest rate for the time delay, if profits are too low to claim the entire tax deduction. The expected value of the ACE would decrease if such a loss carry-forward would not be provided, which might reduce the neutrality characteristics of the ACE tax system" (p. 127), without any denouncement from the OECD of the practicality of these ideas.

Similarly, in discussions of the RRT system, the IMF (2012) states that "As originally designed by Garnaut and Clunies Ross (1975) the uplift rate is set at the minimum required rate of return for the investor; this choice is now widely questioned" (p. 20). Furthermore, "The benchmark result on this issue is that if deferred tax benefits are certain to be ultimately received by the taxpayer (including, if necessary, as payments from the government), then carry forward of unrealized benefits at a risk-free rate is in principle 
appropriate (Fane, 1987; Bond and Devereux, 1995 and 2003). Where there is doubt as to the government's commitment to provide these benefits, riskadjustment for that possibility—which, importantly, does not mean adjusting for the riskiness of companies' own cash flows-is appropriate" (p. 48).

Boadway and Keen (2010) state (in their introduction to an IMF volume summarizing the practical design of actual petroleum taxation systems) that the idea of risk-free deductions has considerable practical importance, "... if tax is fully refundable in the event that the firm ceases operations - corresponding in the resource context to projects that fail to earn a positive lifetime rent-then it is the risk-free rate that should be used [to carry forward costs not yet deducted] in order to preserve neutrality. Intuitively, if the firm is perfectly certain that it will achieve full loss offset in the future then it will value the corresponding tax refunds at the risk-free rate; carrying forward losses at the risk-free rate thus assures their equivalence in present value to immediate refund. Identifying a risk-free rate in practice is problematic, of course. But this result is nevertheless of considerable practical importance for designing any of the present-value equivalent rent taxes described above [...] since it implies that the proper interest rate need not be tailored to the differing circumstances of different firms or projects" (p. 36, emphasis added). We conclude that the IMF has been promoting this type of taxation, with interest accumulation at the risk-free rate, as a practical matter given its assumption that firms accordingly discount these accumulations at the risk-free rate.

Among the academic sources, Lessard (1979) gives a lucid discussion: "Technically, the depreciation tax shields are subject only to the risk that the firm cannot make use of them. This may be serious in certain cases, but in general if the firm cannot take the deductions directly, it can carry them forward or backward in time or, in the ultimate case, transfer them to another firm through merger. Roughly speaking, then, [the discount rate for expected depreciation tax shields] will involve only a small risk premium and can be approximated by the interest rate on the firm's debt in the currency in question (p. 590)." This is related to business taxation in general, without 
any refund arrangement, and with no interest accumulation when deductions are carried forward in time.

In the end, it is important to disentagle the two points raised by Osmundsen et al. (2015), to note how this compares with current concerns in the literature we have cited above, and to clarify the challenges that their points create for tax policy. The first is whether oil firms in Norway identify deductions for capital expenses as approximately riskless or of lower risk than other cash flow streams. The second is whether, if they did, they would nevertheless value them using an exogenous net cash flow discount rate that does not take such risk-reduction into account.

On point one, Osmundsen et al. (2015) agree with the literature in proposing that firms do identify Norwegian tax deductions to be of lower risk than other revenue streams. They then, contrary to the literature and contrary to their own suggestion that a project's discount rate reflects the average risk of that project's cash flow elements as adjudicated by comparable marketed securities (those of firms heavily invested in Norwegian oil and gas), seem to argue that this is immaterial to firms since they cannot value the decrease in risk the same way the government is said to do so; separating and valuing cash flow items in an APV approach is impossible due to a lack of market information as to how to discount those separate cash flow tranches. Given this, firms effectively discount each cash flow item, including near-riskless depreciation allowances, at a market discount rate that is exogenous to the project, their point two. ${ }^{7}$ But as we have stated, if the discount rate is the "correct" or required discount rate that takes into account the risk-reducing effects of taxes on net cash flows, as would be the case when the discount rate is taken from comparable marketed securities, the two approaches will yield the same investment decision. Osmundsen et al. (2015) fail to see that a firm's not following the APV method of valuation assumed by the Norwegian

\footnotetext{
7 In an Appendix Osmundsen et al. (2015) create a series of cash flow examples that include a riskless depreciation schedule, a risky revenue stream, and a riskless investment cost stream to make their point about the impossibility of parsing project cash flows and valuing the parts separately. We have reviewed the examples and find no violation of superposition despite their claims to the contrary.
} 
government does not necessarily mean that they will underinvest in Norwegian oil and gas opportunities.

Furthermore, if firms think and act as theoretical finance models suggest they should, whether discounting the project's after-tax net cash flows at the correct rate or discounting each cash flow item at its correct rate, offering an uplift rate adjusted to the firm's discount rate, as Osmundsen et al. (2015) suggest, can turn a negative before-tax value into a positive aftertax value. Sub-marginal projects will be undertaken under subsidy from the Norwegian government. This pits Norway in a race to the bottom for investment.

As Lund (2014a) notes, despite the advent of APV (and of superposition more generally), it is still of interest to think about the correct rate of discount for project net after-tax cash flows such that one might know how to approximate it from observed market rates of return. To further disentangle these issues, in the next section we produce a model of net cash flow valuation under either certain or risky depreciation allowances.

\section{The model}

This section presents a simple model for the required expected return in a net after-tax cash flow and shows how that return is affected by the specifics of the tax system. In the next section we contrast the approach with that presented in Osmundsen et al. (2015), and we discuss consequences for tax design.

The focus on effects of tax systems is particularly relevant when tax rates are high and deductions substantial, as is recommended for rent taxes (IMF, 2012, p. 6). Standard textbooks (e.g., Brealey et al., 2011, Ch. 9) make it clear that risk adjustments in discount rates should be based on the characteristics of each project. Adelman's "general suspicions regarding the effect of taxation on petroleum supply" are the motivation for Osmundsen et al.'s (2015) paper (p. 196). But in his paper on discount rates used by oil companies and nations, Adelman (1986) supports the textbook argument, admonishing that "To speak of 'the rate' of discount is of course to 
oversimplify" (p. 310). "Risk, unlike beauty, is not in the eye of the beholder; like the mountain, it is simply there. The greater the risk, the lower the present value of a given flow" (p. 313). We show why it is reasonable that the adjustment to the discount rate for project risk take into account the tax system that applies to the project.

The model extends Section 4 of Lund (2014a) to allow for tax deductions that may be subject to political risk. It is very stylized, but sufficient to demonstrate some substantial effects. There is only one future period, only equity financing of the firm, no general inflation, and a very simple tax system. There is only one project under consideration, and tax distortions impact the level of continuous investment, rather than the location of discrete investments. The possibilities of handling more complicated models will be discussed further down. We recognize that petroleum activity may have positive or negative externalities that are not correctly priced by taxes or subsidies or otherwise corrected for. We believe that such problems will be best handled by targeted policies, and leave them out of the current discussion. In the following we also disregard the problem of transfer pricing (or base erosion and profit shifting, BEPS) (Lund, 2002b) which may or may not be handled by targeted policies.

The firm maximizes its market value according to the Capital Asset Pricing Model,

$$
E\left(r_{j}\right)=r+\beta_{j}\left[E\left(r_{m}\right)-r\right],
$$

where $r>\mathrm{O}$ is the appropriate risk-free interest rate, and $\beta_{j}=\operatorname{cov}\left(r_{j}, r_{m}\right) / \operatorname{var}\left(r_{m}\right) .^{8}$ Here, $r_{j}$ and $r_{m}$ are the rates of return on the firm's shares and the market portfolio, respectively. When changes in tax rates or deductions are considered below, these are assumed not to affect the capital market equilibrium. This will be a good approximation for a tax that only applies to a sector that is small in relation to the capital market.

\footnotetext{
${ }^{8}$ The appropriate riskless rate may be an after-tax risk-free rate that takes into consideration tax deductions on interest (Ruback, 1986). See footnote 10 of Lund (2014a) and references therein.
} 
A consequence of the CAPM is that the claim to any uncertain aggregate cash flow $X$, to be received in period 1 , has a period 0 value of

$$
V(X)=\left[E(X)-\lambda \operatorname{cov}\left(X, r_{m}\right)\right] /(1+r),
$$

where $\lambda=\left[E\left(r_{m}\right)-r\right] / \operatorname{var}\left(r_{m}\right)$ and $\left[E(X)-\lambda \operatorname{cov}\left(X, r_{m}\right)\right]$ is known as the risk-adjusted expected cash flow (Constantinides, 1978). Its appropriate discount rate is the risk-free rate. This defines a valuation function $V$ to be applied below. $\quad V \quad$ satisfies value additivity, i.e., $V(a X+b Y)=a V(X)+b V(Y)$ when $a, b$ are non-stochastic.

To discount the expected value of a future risky net cash flow $X$ from a given project, a risk-adjusted discount rate can be used, based on its beta value,

$$
\beta_{X}=\frac{\operatorname{cov}\left(\frac{X}{V(X)}, r_{m}\right)}{\operatorname{var}\left(r_{m}\right)}
$$

In year 0 the firm irreversibly invests an endogenous, optimal amount $I>0$ in a project. In year 1 the project produces a quantity $Q$ to be sold at an uncertain net price $P$. There is a production function with decreasing returns to scale, $Q=f(I)=\kappa I^{v}$, with $\kappa>0, v \in(0,1)$. There is no production flexibility; $Q$ is fixed after the project is initiated. There is no salvage value in period 1 .

A tax at a certain rate $\tau \in[0,1)$ will be paid in year 1 . The tax base is $P Q-c I$, where $c>0$ is a possibly uncertain deduction rate. ${ }^{9} \mathrm{~A}$ pure rent tax would set $V(c)=1$. For now, we assume the tax $\tau(P Q-c I)$ is being paid even when negative, i.e., a negative tax base gives a refund. This is unrealistic for most tax systems when the project stands

\footnotetext{
${ }^{9}$ One simple way to model this is that $c$ could have two outcomes, some statutory deduction rate or zero. That is, there would be a chance that deductions were cancelled altogether. But, more realistically, deduction rates can be reduced (not to zero) or increased in the future, as actually happened in Norway (Lund 2018). This uncertainty in future deduction rates is a major concern in Osmundsen et al. (2015).
} 
alone, but often a good approximation when a project is added to other activity within the firm that is more profitable and only weakly correlated with it. We come back to an alternative assumption.

The cash flow to equity in period 1 is

$$
X=P f(I)-\tau(P f(I)-c I)=P f(I)(1-\tau)+\tau c I,
$$

with $P, c$ as the possibly risky elements. From Eq. (2), the market value of a claim to this cash flow is

$$
V(X)=(1-\tau) V(P) f(I)+\tau V(c) I .
$$

The firm chooses the optimal $I^{*}$ to maximize $V(X)-I$, with first-order condition,

$$
(1-\tau) V(P) f^{\prime}\left(I^{*}\right)=1-\tau V(c) .
$$

In the Appendix we show that, when this is combined with the production function, the beta of the after-tax cash flow $X$ will be a weighted average of the betas of the two risky elements, $P$ and $c$,

$$
\beta_{X}=\frac{1-\tau V(c)}{1-\tau V(c)(1-v)} \beta_{P}+\frac{\tau \nu V(c)}{1-\tau V(c)(1-v)} \beta_{c},
$$

where $v$ is the returns to scale parameter in the production function. Equation (7) emphasizes that the appropriate "theoretical" cash flow discount rate for an optimized project is endogenous to the tax rate, $\tau$, and to the riskiness of deductions for that project, which determines $V(c)$. More to the point of the current discussion regarding the impact of taxation on investment the Appendix shows that the relevant risk adjustment for choosing the optimal scale of investment is based on a marginal beta, which is the limit of Eq. (7) as $\boldsymbol{v} \rightarrow 1$,

$$
\beta_{X m}=(1-\tau V(c)) \beta_{P}+\tau V(c) \beta_{c},
$$

the $X m$ subscript indicating a marginal $\beta_{X}$. The marginal beta is again a weighted average of the betas of the two risky elements, $P$ and $c$. While Eq. (7) characterizes the systematic risk of the project as a whole at optimal scale, the simpler Eq. (8) will be the relevant basis for delegation within the 
firm, to obtain the value-maximizing level of investment. This marginal beta can be thought of as the beta of a marginal project, i.e., the difference between the optimally sized project and a marginally smaller project. ${ }^{10}$ As with Eq. (7), Eq. (8) reveals that the appropriate discount rate for optimization is endogenous to the tax rate and to the riskiness of tax deductions for the project being evaluated.

Osmundsen et al. (2015) recognize that when making investment decisions oil and gas firms will look to similar marketed assets for the appropriate discount rate. But such marketed assets may not reflect taxes similar to that of a specific project being evaluated. Our model suggests an implementation of this approach when tax systems vary widely. The operating cash flows for an oil and gas project, apart from taxation, are more or less the same everywhere. Strictly speaking this is not true, but a simplification. One should be able to find a reasonable market beta for these. In this simple model, this is $\beta_{P}$. The particular tax system makes the difference here between $\beta_{P}, \beta_{X}$, and $\beta_{X m}$, as shown in Eqs. (7) and (8). If firms instead wish to directly select a discount rate that applies to after-tax cash flows, $\beta_{X}$, and $\beta_{X m}$, the marketed assets must be from firms that are subject to a similar tax structure as that of the project.

When the latter approach is used, an example can illustrate the quantitative importance of selecting discount rates from firms that are subject to a similar tax structure as that of the project. For simplicity we index $\beta_{P}=1$ to make the differences between $\beta_{P}, \beta_{X}$, and $\beta_{X m}$ clear. The tax rate is the Norwegian rate, $\tau=0.78$.

Both the RRT and Norwegian petroleum taxes have intentions of $V(c)=1$, in the first case by high future deductions, in the second, by reducing the risk of deductions. If $V(c)=1$ and $\beta_{c}=0$, the latter

\footnotetext{
${ }^{10}$ In an oil field, for example, investment comes in discrete lumps, as in drilling platforms, and the firm decides how many drill platforms to install at a given field. At issue when looking at investment lost due to taxation rules is investment in the marginal platform.
} 
reflecting the fact that any unexpected changes to the tax system are likely to be unsystematic, from Eq. (8) the marginal beta would be $\beta_{X m}=0.22$. As an example of an average beta (Eq. (7)), consider a profitable project with $v=0.5$ so that $V(P) f\left(I^{*}\right)=2 I^{*}$. The average after-tax beta would be $\beta_{X}=0.36$. In each case the downward adjustment of the firm's beta from the pre-tax beta of 1 for risk-reducing tax effects is substantial. If a manager, in making investment decisions, used the pre-tax asset beta of 1 instead of the appropriate beta of 0.22 , as Osmundsen et al. (2015) suggest, there would be underinvestment in projects with guaranteed deductions. Or, if the manager selected an after-tax beta from markets with a different tax structure, there may be under- or over-investment. In the face of a riskless deduction, though, the valuation problem becomes easier than applying this derived beta of 0.22 to the aggregate cash flows because one can simply replace the net revenue stream with its certainty equivalent based on the market-based $\beta_{P}=1$ (see Eq. (2)) and then discount it and the depreciation allowance at the riskless rate to find a present value. This is the fundamentally correct APV approach that Osmundsen et al. (2015) eschew, but that some firms report using in investment analysis.

The analysis does not become substantially more difficult when there is risk in the tax cash flows, as argued by Osmundsen et al. (2015): "Tax carry-forwards can be perceived as a low-risk loan from the companies to the government" (Osmundsen et al., 2015, p. 205). To examine this situation, we assume $\beta_{c}=0.3$, perhaps because there is a chance that the government will reduce some deduction in the future and given the assumption that such actions will be positively correlated with market movements, and $V(c)=0.9$ because of the positive beta and/or somewhat low expected deductions given this beta. With the tax rate of 0.78 , the result from Eq. (8) is $\beta_{X m}=0.51$. This marginal beta, with this small change in the model, is more than twice the marginal beta in the previous example where deductions 
were riskless. For our profitable project with $v=0.5$, the average aftertax beta would be $\beta_{X}=0.62$, again nearly twice the beta when the depreciation allowance was risk free. Both are still considerably lower than the pre-tax cash flow beta of 1 , and it would be astounding if firms did not recognize this effect of taxes on the risks of the after-tax cash flows.

The reason for the substantial effects of taxes in reducing the pre-tax cash flow beta, even when the deductions are considered to be risky, is the fact that "the value of the tax deductions make up the [larger] share of the present value for normal projects." This is actually a quote (our translation) from Osmundsen and Johnsen (2013), p. 17, so there seems to be no disagreement here. The model in the Appendix shows that the relevant project is the marginal project, for which the value of the tax deductions will make up an even larger share than in a normal, more profitable project, and hence result in the lower (marginal) project beta, 0.51 in our example, than the average project beta ( 0.62 in our example).

Looking for similar results for many periods and/or more complicated taxes and/or partly debt-financed firms, one will soon encounter problems that cannot be solved analytically. Jacoby and Laughton (1992) solve such problems with Monte Carlo simulations and are able to characterize average systematic risk in what they call Equivalent Constant Discount Rate. If this is done for a marginal project, the marginal beta can be calculated. It is possible, however, to derive some analytical results in cases where the tax system gives imperfect loss offset. Lund (2014a) looks at the extreme case of this, with no loss offset, i.e., no carry-forward of losses. The government's tax claim is similar to a call option, and option valuation can be applied. Even then, as in the more complicated model in Jacoby and Laughton (1992), taxes typically reduce the systematic risk of after-tax cash flows compared with pre-tax cash flows, especially for marginal projects.

\section{Discussion}


The model presented in the previous section has a cash flow with two risky elements, $P$ and $c$. It was assumed that the betas of these, $\beta_{P}, \beta_{c}$, were determined outside of the model. The model uses these in the determination of the beta of the net after-tax cash flow, $\beta_{X}$ (or $\beta_{X m}$ for a marginal project). In accordance with finance theory it is endogenous, the value-weighted average of betas of cash flow elements with the weights specific to the project under consideration. Osmundsen et al. (2015) assume instead that (what we denote) $\beta_{X}$ is determined outside the model. They then, in a numerical example in Table 1, try out whether a risk-free $c$ can fit into the model. But the remaining part of the cash flow, which is negative ( - in the formulation above, Eq. (4), this is $\operatorname{Pf}(I)(1-\tau)-I$, since investment occurs in the same period the cash flows are received-), must then have what they describe as an unreasonable negative beta. ${ }^{11}$

The basis for taking $\beta_{X}$ as given seems to be that this is observable in the stock market. True enough, for a firm with traded shares, $\beta_{j}$ can be estimated. For the industry as a whole it is approximately 1.4 (Damodaran, 2017). Nevertheless, standard textbooks state explicitly (e.g., Brealey et al., 2011, Ch. 10) that this beta should not be used in investment evaluation. The reason, consistent with Adelman's view, is that each project should be valued based on its own risk, $\beta_{X}$, and not on the average of the portfolio of all projects owned by the firm. We agree, however, that it is useful to consider whether and how a required rate of return can be derived from market data. Our model shows the way, suggesting that a cash flow beta is a more reasonable starting point.

\footnotetext{
11 There is nothing unreasonable about the negative beta, as this is what is needed in their example to convert the negative risky net cash flow, the risk coming from the after-tax income component with $\beta_{P}=0.11$, into an even more negative present value once adjusted for the income risk. Complete APV analysis shows that in their example the riskless investment cash flow is discounted at the risk-free rate, the riskless depreciation cash flow is discounted at the risk-free rate, and the risky after-tax income stream is discounted at $4.69 \%$, reflecting $\beta_{P}=0.11$. The net cash flow beta is $\beta_{X}=0.83$, being leveraged by the investment cash flow.
} 
At this point we may distinguish between several factors that may explain why $\beta_{X m}$ is different from the beta of the firm's shares, or why $r+\beta_{X m}\left(E\left(r_{m}\right)-r\right)$ is different from the average rate of return on the shares. One well-known factor is difference in degree of debt financing ("leverage"). We don't see any disagreement on this. Then there is a question whether the firm's shares are observed over a long enough period, and whether they are representative of the industry. We would recommend using an average across many firms with similar activities. But the variety of tax systems applied in the petroleum sector raises a particular concern. We have shown in the previous section that tax systems may lead to substantial divergence between $\beta_{P}$ and $\beta_{X}$, and that $\beta_{X}$ (and $\beta_{X m}$ ) themselves are sensitive to differences in tax systems and are not likely to be approximated by an average $\bar{\beta}_{j}$ even after adjustment for financial leverage. ${ }^{12}$ This suggests either to use data for $\beta_{X}$ for firms that operate only under a tax system representative of the jurisdiction of the investment, or to set up a model like ours to attempt to quantify the effect of different tax systems. The latter is more realistic, since few firms operate in only one industry within only one country. Stock market data for such firms could be less representative for other reasons, and, in any case, very limited compared with data available for specific cash flow components like oil revenue.

The very simple model in Section 4 could be applied with different tax parameters in those countries where a firm has substantial operations. A weighted average of the betas for these should be consistent with the beta of the firm's shares. We have no illusions that such calculations easily will result in different required rates of returns to be applied in different countries, consistent with observed stock market data for each multinational firm. There are sufficiently many deviations between stock market data and economic activity that we cannot expect any perfect fit. However, it is unreasonable to

12 Damodaran (2017) calculates an unleveraged average industry beta of 1. 
recommend capital budgeting methods that do not take into account the strong tax effects that were shown in Section 4.

The substantial effects on after-tax betas of a rent tax with high rate and high deductions are, of course, different from effects of ordinary corporate income taxes. This explains why there is less attention to this mechanism in textbooks. Osmundsen et al. (2015, p. 196) quote the following paragraph from Brealey et al. (2008, p. 561):

Capital projects are normally valued by discounting the total after-tax cash flow they are expected to generate.

Depreciation tax shields contribute to project cash flow, but they are not valued separately; they are just folded into project cash flows along with dozens, or hundreds, of other specific inflows and outflows. The project's opportunity cost of capital reflects the average risk of the resulting aggregate.

This is a reasonable practice for firms operating under low tax rates, and in particular if they operate in only one jurisdiction. However, Osmundsen et al. (2015) omit the subsequent paragraph from Brealey et al. (2008, p. 561):

\footnotetext{
However, suppose we ask what depreciation tax shields are worth by themselves. For a firm that's sure to pay taxes, depreciation tax shields are a safe, nominal flow.

Therefore, they should be discounted at the firm's after-tax borrowing rate.
}

Seen together, we believe the two quotes support the view that when tax deductions make up an unusually large fraction of future cash flows, there are good reasons for firms to consider whether these deductions contribute to reducing risk and to include such risk reductions in decision making. 
The consequences for petroleum taxation are not immediate. Osmundsen et al. (2015) claim that each oil company bases its decisions on the use of one required rate of return (i.e., one discount rate), presumably applied across different jurisdictions without any adjustment for the systematic risk of tax deductions. They claim (p. 198) that the method which splits cash flows in different elements is "unusable in practice." They do not explicitly discuss whether the single discount rate applied to net cash flows should be adjusted for differences in tax systems, but the implication seems to be that this is also impracticable. Their suggestion for tax policy seems to be to rely on the required expected after-tax return reported by oil companies, and base the petroleum tax system on this, if needed. They also mention an alternative solution, to use pure cash flow taxation. We agree that this would solve the problem encountered in most existing rent tax systems, the need to protect the required return to equity, which is not immediately observable.

However, we cannot recommend to simply ask the taxpayers what are their required returns. We have also shown in Section 3 that there are strong indications that a number of oil companies have started to use more advanced decision methods. Competition between companies can lead those companies with lower costs to succeed. This is also true for companies applying lower costs of capital in their decision making. As is well known in the finance literature, efficient markets do not require that all investors behave rationally, only that some do. And, as we have pointed out, surveys report a substantial subset of companies using special discount rates for depreciation allowances. The divergence between this view and the view of Osmundsen et al. (2015) seems to be based partly on a difference over what decision criterion would maximize the values of firms. Since Osmundsen et al. (2015) take a given after-tax beta value from the stock market as their point of departure, and do not accept that there should be any adjustment for the different risks of different tax systems, they have not identified any need for companies to take this difference in risk into account. It is only natural, then, to base tax systems on the same constant discount rate applied everywhere. 
But they should recognize that this is at odds with Summers (1987), instead of claiming that their approach is similar to his.

The criticism of the Ministry of Finance of Norway (Osmundsen et al., 2015, pp. 197-201, p. 204) disregards the fact that the Ministry follows recommendations from the OECD and the IMF. It would be appropriate to direct much of the same criticism against these organizations, the Mirrlees Review, and the numerous academic articles that support their viewpoints. It would be appropriate also to mention that the same issues are relevant for some of the most important current proposals for tax reform, based on the ACE system for business taxation in general, and on the RRT system for rent taxation. The abrupt reference to "this debate" (p. 199 and the final paragraph) suggests that there is a much larger debate, but only Fane (1987) and Summers (1987) are cited out of those that have somewhat different viewpoints. Curiously, Laughton (1998), which supports the APV approach, appears in the reference list, but not in the main text.

Apart from this, there are some other weaknesses in Osmundsen et al.'s (2015) analysis. They claim (p. 205) that they apply principal-agent theory. This is reduced to a trivial point, however, since they claim there is no asymmetry of information in this case. They believe the authorities have reliable information on the decision criteria of the oil companies. There is thus a sharp difference to the previous work of Osmundsen (1995), who relies on an assumption of asymmetric information. We cannot see that the 1995 approach is immediately applicable, but we think the symmetric-information assumption is too simple. Oil companies world wide have a clear interest in overstating their required rates of return, in particular to tax authorities, since this is an argument for higher deductions, thus lower tax payments.

Another has to do with the IRR criterion, which is incorrectly applied. Osmundsen et al. (2015) state (p. 201) that "The starting point for tax design is neutrality - the internal rate of return is the same before and after tax." This is repeated in the middle of p. 204. It is a misleading definition of tax neutrality, even if we restrict attention to situations with full certainty. The definition they give on p. 196, based on NPV, is correct. True enough, a 
neutral tax will typically not affect the internal rate of return of a marginal project. That is, a project which has a net value of zero before the tax is applied, will also have a net value of zero after the tax, and the project is thus on the borderline between profitable and unprofitable. Under full certainty this means that the internal rates of return are the same before and after tax for the marginal project. But for a profitable project, there is no reason why a neutral tax should not affect the IRR. Actually, much of the discussion has to do with the accumulation of interest when deductions are postponed. If a project has a positive NPV, and thus an IRR exceeding the interest rate, it is clear that a postponement with interest accumulation that does not affect the NPV would affect the IRR. Only if the IRR is equal to the interest rate will the postponement with interest have zero effect on the IRR.

A final weakness has to do with uncertainty of future tax deductions resulting from uncertainty of future costs. Osmundsen et al. (2015) point out (p. 205) that tax deductions are not risk free, in part due to "the risk of the size of the investment cost." This point is irrelevant in connection with tax neutrality. The authors agree (p. 197) with the basic insight that a pure cash flow tax is neutral. Clearly, in a pure cash flow tax system, when future investment costs are uncertain, the tax deductions for these costs are equally uncertain. This does not contradict neutrality. On the contrary, it is a condition for neutrality, see Boadway and Keen (2015, p. 108). When the tax system instead allows deductions that are postponed, relative to the costs, this does not create any additional tax distortion. Our previous discussion applies to the deductions conditional on the costs that will be realized.

\section{Conclusion}

Adelman notes with respect to firm and nation oil and gas discount rates, "Their actions may reveal their preferences more accurately than could their words" (1986, p. 309). The decision processes of multinational firms are not fully revealed to the public, nor to authorities, and probably never will be. While they use economic theory for guidance, there is no reason to believe that an exact (simple or complex) decision criterion is applied. New methods 
are being introduced gradually. If firms want to maximize market value, there are good reasons for them to consider how tax systems affect the risk characteristics of their after-tax cash flows. A simple model has illustrated that taxes can have substantial effects on project betas and hence project discount rates, both average and marginal.

International organizations like the IMF and the OECD, as well as leading tax experts, as expressed in the Mirrlees Review, have given recommendations on tax reforms, both for business taxation in general and for taxation of natural resource rent. An explicit underlying assumption has been to regard future tax deductions as much less risky than other cash flow elements, from the firms' point of view. Some references have regarded the deductions as risk free, while some have pointed out the risk that the tax value of deductions may not be earned effectively if the firm never pays taxes.

In designing a petroleum tax system, the Ministry of Finance of Norway is largely in accordance with the advice of the IMF and the OECD. Tax deductions are carried forward with interest, and if an oil company closes down before earning the tax value of these, the balance is refunded. As long as current rules are unchanged, this means that deductions are risk free. Large refunds have been made and received public attention, but the system has survived changes of government between the political blocks, so the political risk connected to these deductions seems to be small. Much of the criticism by Osmundsen et al. (2015) is misplaced, not only in principle, but in practice.

Osmundsen et al. (2015) point out that Adelman was suspicious of the distortionary effects of taxation on petroleum investment and production decisions. His writings provide no inference that petroleum companies ignored the theoretical complexities of optimal investment decision making (Cairns and Davis, 2015), including how taxes impact that optimality. Since firms behave differently and adopt new methods gradually, tax authorities cannot rely on all firms behaving according to one theory. Competition between firms can help so that firms adopting the more advanced theories will outperform other firms. There is no guarantee that this will work perfectly, but the alternative suggested is to rely on firms being stuck with outdated 
methods (- using one discount rate in all jurisdictions for all projects-) which are denounced by standard textbooks. Firms have an interest in exaggerating their required returns. If authorities base taxation on the claims that are put forward, there will be some cases of overinvestment, i.e., firms investing more, at the margin, than they would have done in the absence of rent taxation since such taxation turns into a subsidy. If authorities base taxation on the theories suggested here, some firms may not realize the potential values, and there may be underinvestment at the margin. Neither of these deviations is desirable, but the potential harm is low, either way. After all, close to the margin, the net deadweight losses are low. In a wider context it may be better to base taxation on the theories suggested here and encourage firms that adopt newer methods, as they will undoubtedly use decision methods over all aspects of asset management that produce results closer to the optimum.

\section{Appendix}

We first derive Eq. (7). The first-order condition Eq. (6) can be rewritten, based on the analytical production function, as

$$
V(P) f(I)(1-\tau)=(1-\tau V(c)) I / v .
$$

The after-tax asset beta is a value-weighted average of the (return) betas of the two elements of the cash flow in Eq. (4),

$$
\begin{aligned}
& \beta_{X}=\frac{f(I)(1-\tau) V(P)}{f(I)(1-\tau) V(P)+\tau I V(c)} \beta_{P}+\frac{\tau I V(c)}{f(I)(1-\tau) V(P)+\tau I V(c)} \beta_{c} \\
& =\frac{(f(I) / I)(1-\tau) V(P)}{(f(I) / I)(1-\tau) V(P)+\tau V(c)} \beta_{P}+\frac{\tau V(c)}{(f(I) / I)(1-\tau) V(P)+\tau V(c)} \beta_{c} .
\end{aligned}
$$


The formulation after the last equality sign shows that this $\beta_{X}$ depends on one, and only one, characteristic of the project, namely, the ratio $V(P) f(I) / I$. This is an expression for the average profitability of the project, which determines the relative magnitudes of the two terms in (4), one proportional to $f(I)$, the other proportional to $I$. A project with more rent relative to investment will have more weight on $\beta_{P}$, less on $\beta_{c}$, and a higher after-tax discount rate when $\beta_{c}<\beta_{P}$. Through the first-order condition (9), the ratio $V(P) f\left(I^{*}\right) / I^{*}$ is determined by $v$ and variables that are exogenous to the project. Using the first-order condition and the parameterized production function, Eq. (10) can be simplified to Eq. (7), reproduced here:

$$
\beta_{X}=\frac{1-\tau V(c)}{1-\tau V(c)(1-v)} \beta_{P}+\frac{\tau \nu V(c)}{1-\tau V(c)(1-v)} \beta_{c} .
$$

Since $\beta_{X}$ depends on average profitability, the marginal unit invested, based on the optimal decision, will have a different $\beta_{X}$. The following is an extension of proposition 2 in Lund (2014a) to this case with a risky tax deduction. We show that the value-maximizing decision can be made on the basis of a marginal beta. This can be found in the limit as $v \rightarrow 1$, i.e., like a project with constant returns to scale and zero net value. The resulting $\beta_{X m}$ is given by Eq. (8) in the main text.

We now show that when this is used for a risk-adjusted discount rate, it results in the value-maximizing decision as proposed in Eq. (6).

The proposed risk-adjusted discount rate is

$$
r+\beta_{X m}\left(E\left(r_{m}\right)-r\right) .
$$

The maximand is then 


$$
\frac{E(P) f(I)(1-\tau)+\tau E(c) I}{1+r+\beta_{X m}\left(E\left(r_{m}\right)-r\right)}-I .
$$

The first-order condition for a maximum w.r.t. $I$ is

$$
\frac{E(P) f^{\prime}(I)(1-\tau)+\tau E(c)}{1+r+\beta_{X m}\left(E\left(r_{m}\right)-r\right)}=1 .
$$

It remains to show that this has the same solution for $I^{*}$ as Eq. (6) in the main text.

The two valuation expressions $V(P)$ and $V(c)$ both satisfy the CAPM. This implies

$$
V(P)=\frac{E(P)}{1+r+\beta_{P}\left(E\left(r_{m}\right)-r\right)},
$$

and a similar expression for $V(c)$. When the values that these imply for $E(P)$ and $E(c)$ are plugged into Eq. (13), we find

$$
\begin{aligned}
V(P)(1 & \left.+r+\beta_{P}\left(E\left(r_{m}\right)-r\right)\right) f^{\prime}(I)(1-\tau)+\tau V(c)\left(1+r+\beta_{c}\left(E\left(r_{m}\right)-r\right)\right)=1+r+\beta_{X m}\left(E\left(r_{m}\right)-r\right) \\
& =1+r+\left[(1-\tau V(c)) \beta_{P}+\tau V(c) \beta_{c}\right]\left(E\left(r_{m}\right)-r\right) .
\end{aligned}
$$

The term $\tau V(c) \beta_{c}\left(E\left(r_{m}\right)-r\right)$ can be subtracted on both sides. The remaining terms can be rearranged into

$V(P) f^{\prime}(I)(1-\tau)=\frac{(1+r)(1-\tau V(c))+(1-\tau V(c)) \beta_{P}\left(E\left(r_{m}\right)-r\right)}{1+r+\beta_{P}\left(E\left(r_{m}\right)-r\right)}$,

which can be simplified into Eq. (6), q.e.d.

\section{Acknowledgements}


Lund was a member of the Norwegian public commission on petroleum taxation 1999-2000, but has not participated in the Ministry's work with subsequent reforms of the system. Lund's research is part of the activities of the research center Oslo Fiscal Studies, which is supported by The Research Council of Norway. Useful comments during presentation at the IAEE 41st international conference in Groningen, 2018, and from two referees, are gratefully acknowledged. 


\section{References}

Adelman, M. A. (1986). “Oil Producing Countries' Discount Rates.” Resources and Energy 8: 309-329.

Bailey, W., B. Couët, A. Bhandari, S. Faiz, S. Srinivasan and H. Weeds (2003). "Unlocking the Value of Real Options." Oilfield Review, Winter 2003/2004: 9-19.

Baker, H. K., S. Dutta and S. Saadi (2011). "Management Views on Real Options in Capital Budgeting." Journal of Applied Finance 1: 18-29.

Ball, R. and J. Bowers (1983). "Distortions Created by Taxes which are Options on Value Creation: The Australian Resources Rent Tax Proposal." Australian Journal of Management 8: 1-14.

Boadway, R. and N. Bruce (1984). "A General Proposition on the Design of a Neutral Business Tax.” Journal of Public Economics 24: 231-239.

Boadway, R. and M. Keen (2010). "Theoretical Perspectives on Resource Tax Design.” In: Daniel, P., M. Keen and C. McPherson (eds.), The Taxation of Petroleum and Minerals: Principles, Problems and Practice, New York: Routledge, 13-74.

Boadway, R. and M. Keen (2015). "Rent Taxes and Royalties in Designing Fiscal Regimes for Nonrenewable Resources.” In: Halvorsen, R., and D.F. Layton (eds.), Handbook on the Economics of Natural Resources, Cheltenham, UK: Edward Elgar, 97-139.

Bonaime, A., H. Gule and M. Ion (2018). "Does Policy Uncertainty Affect Mergers and Acquisitions?” Journal of Financial Economics 129: 531558.

Bradner, T. (2016). "Walker vetoes credits.” Petroleum News 21(27). Anchorage, Alaska. Available at http://www.petroleumnews.com/pnfriends/724974894.shtml, downloaded Sept. 23, 2016.

Bradner, T. (2017). "Alaska lawmakers change oil and gas production tax, end cash payments." Available at https://www.platts.com/latestnews/oil/anchorage-alaska/alaska-lawmakers-change-oil-and-gasproduction-21349655, downloaded Jan. 25, 2018.

Brealey, R. A., S. C. Myers and F. Allen (2008). Principles of Corporate Finance. New York: McGraw-Hill, 9th ed.

Brealey, R. A., S. C. Myers and F. Allen (2011). Principles of Corporate Finance. New York: McGraw-Hill, 10th ed. Global edition.

Brown, E. C. (1948). "Business Income, Taxation, and Investment Incentives.” In: Metzler, L., H. S. Perloff and E. D. Domar (eds.), Income, Employment, and Public Policy: Essays in Honor of Alvin H. Hansen, New York: Norton, 300-316.

Brounen, D., A. de Jong and K. Koedijk (2004). "Corporate Finance in Europe: Confronting Theory with Practice." Financial Management (Winter): 71-101.

Cairns, R. D. and G. A. Davis (2015). "Mineral Depletion and the Rules of Resource Dynamics." The Energy Journal 36(SI 1): 159-178. 
Constantinides, G. M. (1978). "Market Risk Adjustment in Project Valuation." Journal of Finance 33(2): 603-616.

Damodaran, A. (2017). Betas by Sector (US). Available at http://pages.stern.nyu.edu/ adamodar/New_Home_Page/datafile/Betas.ht ml, downloaded Feb. 16, 2017.

Daniel, P. and E. M. Sunley (2010). "Contractual Assurances of Fiscal Stability.” In: Daniel, P., M. Keen and C. McPherson (eds.), The Taxation of Petroleum and Minerals: Principles, Problems and Practice, New York: Routledge, 405-424.

de Mooij, R. A. and M. P. Devereux (2011). "An Applied Analysis of ACE and CBIT reforms in the EU." International Tax and Public Finance 18: 93-120.

de Souza, Luiz Gustavo (2014). "Better Tools for the Valuation of Petroleum Assets." Oil \& Gas Financial Journal, 11(8).

Dowell, R. (1978). "Resources Rent Taxation.” Australian Journal of Management 3: 127-146.

Emhjellen, M. and C. M. Alaouze (2002). "Project Valuation when there are Two Cash Flow Streams.” Energy Economics 24: 455-467.

Emhjellen, M. and C. M. Alaouze (2003). “A Comparison of Discounted Cashflow and Modern Asset Pricing Methods-Project Selection and Policy Implications.” Energy Economics 31: 1213-1220.

Emhjellen, M. and P. Osmundsen (2011). "Separate Cash Flow ValuationApplications to Investment Decisions and Tax Design." International Journal of Global Energy Issues 35(1): 43-63.

Fane, G. (1987). "Neutral Taxation under Uncertainty." Journal of Public Economics 33: 95-105.

Garnaut, R. and A. Clunies Ross (1975). "Uncertainty, Risk Aversion and the Taxing of Natural Resource Projects." Economic Journal 85: 272287.

Graham, J. H. and C. R. Harvey (2001). "The Theory and Practice of Corporate Finance: Evidence from the Field." Journal of Financial Economics 60: 187-243.

Harchaoui, T. M. and P. Lasserre (2001).“Testing the Option Value Theory of Irreversible Investment.” International Economic Review 42(1): 141166.

Horn, A., F. Kjærland, P. Molnár and B. W. Steen (2015). “The Use of Real Option Theory in Scandinavia's Largest Companies." International Review of Financial Analysis 41: 74-81.

IFS (1991). "Equity for Companies: A Corporation Tax for the 1990s." Report of the IFS Capital Taxes Group, April, Institute for Fiscal Studies, London.

IMF (2012). "Fiscal Regimes for Extractive Industries: Design and Implementation." Report Prepared for the Fiscal Affairs Department, 15 August, International Monetary Fund, Washington, D.C.

Jacoby, H. D. and D. G. Laughton (1992). "Project Evaluation: A Practical Asset Pricing Method." The Energy Journal 13(2): 19-47.

Jensen, S. (2017). “Oljen, vårt sikreste kort," (The oil, our safest bet). Klassekampen, Oslo, January 21, p. 42. Available at 
https://www.regjeringen.no/no/aktuelt/debattinnlegg-den-viktigeoljeskatten/id2536096/, downloaded June 22, 2017.

Laughton, D. G. (1998). “Introduction.” The Energy Journal 19(1): 1-11.

Leslie, K. J. and M. P. Michaels (1997) "The Real Power of Real Options." McKinsey Quarterly, Number 3, 4-23.

Lessard, D. R. (1979). "Evaluating Foreign Projects: An Adjusted Present Value Approach.” In: Lessard, D. R. (ed.), International Financial Management: Theory and Application, Boston: Warren, Gorham \& Lamont, 577-592.

Lintner, J. (1965). "The Valuation of Risk Assets and the Selection of Risky Investments in Stock Portfolios and Capital Budgets." Review of Economics and Statistics 47: 13-37.

Lund, D. (2002a). "Petroleum Tax Reform Proposals in Norway and Denmark." The Energy Journal 23: 37-56.

Lund, D. (2002b). "Rent Taxation when Cost Monitoring is Imperfect." Resource and Energy Economics 24: 211-228.

Lund, D. (2013). "Bedre omtrent riktig enn nøyaktig galt (Better approximately right than exactly wrong)." Samfunnsфkonomen 127(9): 14-18.

Lund, D. (2014a). "How Taxes on Firms Reduce the Risk of After-Tax Cash Flows.” FinanzArchiv/Public Finance Analysis 70: 567-598.

Lund, D. (2014b). "State Participation and Taxation in Norwegian Petroleum: Lessons for Others?" Energy Strategy Reviews 3, 49-54.

Lund, D. (2018). "Increasing resource rent taxation when the corporate income tax is reduced?" Memorandum no. 03/2018, Department of Economics, University of Oslo.

Mayo, W. (1979). "Rent Royalties.” Economic Record 55: 202-213.

Ministry of Finance (2012). "Endringar i skatte-, avgifts- og tollovgivinga," (Changes in tax and customs legislation). Prop. 150 LS 2012-13 (White Paper), Oslo.

Mirrlees, J., S. Adam, T. Besley, R. Blundell, S. Bond, R. Chote, M. Gammie, P. Johnson, G. Myles and J. Poterba (eds.) (2011). Tax by Design: The Mirrlees Review. Oxford: Oxford University Press for the Institute for Fiscal Studies.

Moel, A. and P. Tufano (2002). "When are Real Options Exercised? An Empirical Study of Mine Closings." Review of Financial Studies 15(1): 35-64.

Mossin, J. (1966). "Equilibrium in a Capital Asset Market." Econometrica 34: 261-276.

Muehlenbachs, L. (2015). “A Dynamic Model of Cleanup: Estimating Sunk Costs in Oil and Gas Production." International Economic Review 56(1): $155-185$

Myers, S. C. (1974). "Interactions of Corporate Financing Decisions and Investment Decisions - Implications for Capital Budgeting." Journal of Finance 29: 1-25.

Myers, S. C (1984). "Finance Theory and Financial Strategy." Interfaces 14(1): 126-137. 
OECD (2007). Fundamental Reform of Corporate Income Tax. Paris: OECD Tax Policy Studies 16.

Osmundsen, P. (1995). "Taxation of Petroleum Companies Possessing Private Information." Resource and Energy Economics 17: 357-377.

Osmundsen, P. (2010). "Time Inconsistency in Petroleum Taxation: Lessons from Norway.” In: Daniel, P., M. Keen and C. McPherson (eds.), The Taxation of Petroleum and Minerals: Principles, Problems, and Practice, New York: Routledge, 425-444.

Osmundsen, P. and T. Johnsen (2013). "Petroleumsbeskatning. Teori og virkelighet (Petroleum Taxation. Theory and Reality)." Samfunnsøkonomen 127(5): 13-21.

Osmundsen, P., M. Emhjellen, T. Johnsen, A. Kemp and C. Riis (2015). "Petroleum Taxation Contingent on Counter-factual Investment Behaviour." The Energy Journal 36(SI 1): 195-213.

Radulescu, D. M. and M. Stimmelmayr (2007). "ACE versus CBIT: Which is Better for Investment and Welfare?" CESifo Economic Studies 53: 294-328.

Ross, S. A., R. W. Westerfield and B. D. Jordan (2010). Fundamentals of Corporate Finance. New York: McGraw-Hill Irwin, 9th ed.

Ruback, R. (1986). "Calculating the Present Value of Riskless Cash Flows." Journal of Financial Economics 15: 323-339.

Ryan, P. A. and G. P. Ryan (2002). "Capital Budgeting Practices of the Fortune 1000: How Have Things Changed?" Journal of Business and Management 8(4): 355-364.

Salahor, G. (1998). "Implications of Output Price Risk and Operating Leverage for the Evaluation of Petroleum Development Projects." The Energy Journal 19(1): 13-46.

Samis, M., G. A. Davis, D. Laughton and R. Poulin (2006). "Valuing Uncertain Cash Flows When There Are No Options: A Real Options Approach.” Resources Policy 30: 285-298.

Sharpe, W. F. (1964). "Capital Asset Prices: A Theory of Market Equilibrium under Conditions of Risk." Journal of Finance 19: 425-442.

Smith, B. (1999). "The Impossibility of a Neutral Resource Rent Tax." Working paper in economics and econometrics 380, Australian National University, Canberra.

Summers, L. H. (1987). "Investment Incentives and the Discounting of Depreciation Allowances." In: Feldstein, M. (ed.), The Effects of Taxation on Capital Accumulation, Chicago: University of Chicago Press, 295-304. 